\section{I $\mathbf{B}$ A Institute of \\ YK Business Administration \\ तर Karachi \\ Leadership and Ideas for Tomorrow}

Article 1
Volume 6 Issue 2

July-December 2011

\section{Business Review}

7-1-2011

\title{
Front Matter of Volume 6 Number 2
}

Tufail A. Qureshi

Institute of Business Administration, Karachi, Pakistan

Follow this and additional works at: https://ir.iba.edu.pk/businessreview

Part of the Business Commons

c) (i)

This work is licensed under a Creative Commons Attribution 4.0 International License.

\section{Recommended Citation}

Qureshi, T. A. (2011). Front Matter of Volume 6 Number 2. Business Review, 6(2), 1-8. Retrieved from https://doi.org/10.54784/1990-6587.1189

This article is brought to you by iRepository for open access under the Creative Commons Attribution 4.0 License and is available at https://ir.iba.edu.pk/businessreview/vol6/iss2/1. For more information, please contact irepository@iba.edu.pk. 


\section{Title Inside}

Volume 6 Number 2

July - December 2011

\section{IBA \\ YK BUSINESS REVIEW \\ त्रর}

Chairman Board of Editors

Editor

Ishrat HUSAIN

Tufail A. QURESHI

\section{INTERNATIONAL EDITORIAL BOARD}

Deepak KAPUR

Institute of Management Technology

Ghaziabad, UP, India

Khurshid M. KIANI

Bang College of Business Almaty,

Republic of Kazakhstan

\section{S.W.S.B. DASANAYAKA}

University of Moratuwa Sri Lanka

Menno ADEN

Technische University Dortmund

Germany

Liu Jun YING

Jinanjin University, Jian Jin China

Naved AHMED

Institute of Business Administration

Karachi-Pakistan

M. Aminul ISLAM

University Sain, Malaysia

Bettina ROBOTKA

Humbolt University, Berlin Germany

Akif HASSAN

Iqra University,

Karachi-Pakistan

Khursheed OMER

University of Houston Downtown Texas, USA

Zeenat ISMAIL

Institute of Business Administration

Karachi-Pakistan

\section{Arun Diwaker Nath BAJPAI}

Rani Durgavati University Jabalpur, MP, India

Talat A. WAZARAT

Institute of Business Administration

Karachi-Pakistan

Shamas-ur-Rehman TOOR

University of New South Wales Australia

Khadija Malik BARI

Institute of Business Administration

Karachi-Pakistan

Ahmed Audu MAIYAKI

Bayero University, Kano Nigeria

Agung NUGROHO

Atma Jaya Cotholic University Jakarta, Indonesia

Faisal Manzoor ARAIN

Southern Alberta Institute of Technology

Canada

Low Sui PHENG

National University of Singapore

Singapore

Badar Alam IQBAL

Aligarh muslim University Aligarh (UP), India

Abdul RASHID

Intrnational Islamic University

Islamabad-Pakistan

Mirza Sardar HUSSAIN

Institute of Business Administration

Karachi-Pakistan

Business Review is a peer reviewed bi-annual research journal of the Institute of Business Administration (IBA) Karachi. It is recognized by the

Higher Education Commission (HEC) of Pakistan and is internationally abstracted/ indexed in the Journal of Economic Literature (JEL) and EBSCO database. 


\title{
BUSINESS REVIEW
}

\author{
IBA \\ yk
}

RESEARCH JOURNAL

of

THE INSTITUTE OF BUSINESS ADMINISTRATION

KARACHI - PAKISTAN 


\section{CONTENTS}

Editorial Perspective

\section{ARTICLES}

Soziale Marktwirtschaft - Key to Economic Success or

Contradictio in Adiecto: Menno Aden

Firm Growth and Industrial Clusters: Implications for Latecomer

Developing Countries: Babur Wasim Arif \& Sajid Manzoor Asadi

The Socio-demographic Progression of the Pakistani Woman Manager 1988 to 2004 an Empirical Evidence from the Private Sector: Shehla

Riza Arifeen. $-34$

An Information Technology (IT) Based Approach for Enhancing Prompt and Effective Post-disaster Reconstruction: Faisal Manzoor Arain 67

Impact of Exchange Rate Depreciation on Domestic Output in Pakistan:

Muhammad Afzal.

\section{DISCUSSION}

Type A-b Personality and Locus of Control: A Combined Factor Determining Job Satisfaction: Afia Hanif \& Sarwat Sultan 90

Financial Development and Firms' Growth in Textile Industry of Pakistan: A Panel Data Analysis: Ijaz Hussain 97

\section{CASE STUDY}

Succession in Family Businesses: Kinship Culture and Islamic Law of Inheritance: Nasir Afghan

Factors Influencing Malaysian Muslims to Patronage Halal Restaurants - Ambience as a Mediator: Tawfik Salah Mohammed Al-Nahdi \&

Md. Aminul Islam 119

\section{BOOK REVIEW}

Development Policy Sans the Politics of Development: A Review of S.N.H Naqvi: The Evolution of Development Policy: Javed Ansari 


\title{
Title Inside Back
}

\section{IBA}

\author{
Research Journal \\ of \\ The Institute of Business Administration \\ Karachi, Pakistan
}

\section{Guidelines for Contributors}

Business Review is a biannual publication of the Institute of Business Administration, Karachi, Pakistan. It is a multidisciplinary journal covering a wide range of issues in the areas of business, social and management sciences, administration and governance, mathematics and computer studies, finance, economics, psychology, business ethics, logic, history of ideas, and philosophy of comparative religion.

\section{Guidelines for Authors}

1. The journal invites the following types of contributions:

- $\quad$ Research papers

- $\quad$ Case studies and discussion papers

- $\quad$ Articles/ Book Reviews

- Brief reports and comments

2. Manuscript should be submitted to the Editor, Business Review, Institute of Business Administration, University Road, Karachi, Pakistan.

3. Three copies of the manuscript should be submitted.

4. The text should be double spaced, on one side of the quarto paper allowing wide margins for referee's comments.

5. All illustrations, tables, etc., should be placed on separate sheets, included with each copy. Their placement should be indicated in the text.

6. $\quad$ Footnotes should be numbered consecutively through the text.

7. The first page of the manu script should contain the following information. (i) title of the paper; (ii) the names(s) and institute affiliation(s) of the author(s); (iii) a footnote should give the name, postal address, telephone and fax number, and an email address of the authors.

8. The second page must contain the title, and abstract not exceeding 300 words, a maximum of 5 key words or phrases and appropriate JEL codes to be used for indexing purpose. The text will start on page number 3 .

9. Acknowledgements of all sorts should be included on the first page.

10. All mathematical derivations should be presented on a separate sheet, (not to be published) to help the referees.

11. Manuscript should include only those references that are cited in the text. Authors are advised to follow American Psychological As sociation (APA) style of referencing.

12. All literary material, including books, journals and manuscripts for review should be submitted in triplicate to the Editor, Business Review, Institute of Business Administration, University Road, Karachi, Pakistan.

13. It is assumed that the paper submitted is an original unpublished work and it has not already been published or submitted for publication elsewhere.

14. The opinions, ideas and evaluations expressed in the articles printed in the Business Review do not necessarily

represent the views or policies of The Institute of Business Administration or the Editorial Board. They should be considered as representative example of opinions and analysis now current in the academic field on various subjects of intellectual, educational and cultural interest.

15. After internal evaluation, the Editor will send the selected articles to the external referees or the consulting foreign editors for their evaluation. Selection of the referees will be the discretion of the Editor.

16. The articles will be evaluated through anonymous peer reviews. Papers will normally be scrutinized and commented on by at least two independent expert referees in addition to the Editor or Associate Editor, usually the members of editorial board. The referees will not be made aware of the identity of the author. All information about authorship will be removed from the papers.

17. The text of this publication or any part thereof may not be reproduced in any formor manner whatsoever without the permission in writing form the editor.

For advance electronic submission of the material:

businessreview@iba.edu.pk

tufail.qureshi@gmail.com

tqureshi@iba.edu.pk

All enquiries should be addressed to the Editor, Business Review, Research Joumal of The Institute of Business Administration, Karachi, Pakistan. 


\section{EDTORIAL PERSPECTIVE}

Drucker discusses economic life in terms of values, integrity, character, knowledge, vision, responsibility, self-control, social integration, teamwork, community, competence, social responsibility, the quality of life, selffulfillment, leadership, duty, purpose, dignity, meaning - but rarely money. He defends profit, but as if it were brocolli: a distasteful obligation of managers who would rather be reading Kierkegaard.

The World According to Drucker, Jack Beatty

There always comes a time in the life of a thinking man when he repents the thoughts he did not think, the emotions he did not feel and the decisions he did not make. In life, as in philosophy, ethics, morality, management, and evaluative judgments, everything depends upon taking a position. Likewise, at some point of it's historical existence, each society is confronted with the decisive moment when a hard earned glory or a well deserved grief becomes the defining feature of it's raison d'etre. Strange are the ways of life and stranger still are the ways of man. Thoughtfully, we all look back but cannot re-live the past; in retrospect, we are all wiser.

Often we look deep and long into the future to realize that time is our scarcity. Yet, we all have time, enough to celebrate our achievements, and to feel sad or wax indignance over what we could have done but did not do. Yes, we all have time, enough to vie in good deeds and to compete on excellence. Even if we do not have time in abundance, we still can contemporize our vision of what ought to be. However brief, there is always enough time for our creative rage and iconoclastic frenzy.

The most challenging task a corporate manager faces today is the need to translate the spirit of his vision into the ground based realities of the corporate world. He will be tried and tested by his success or failure to incorporate his creative will and normative intentions into his world-view, to reflect the transcendental dimension of the dynamic principle of movement in the corporate culture.

We are familiar with those who have misgivings about the role of ethics in the elusive and hard to measure factor of corporate management. They do not share our hope that if we could only draw morality into the fold of corporate world-view, it will alter our relationship to our thought and action. Maybe it is our bias speaking, but since it is a matter of great pedagogical importance we need to think of the "Concerns of College Students Regarding Business Ethics" (Journal of Business Ethics, 3, 195-200, 1984, Beltramini, R. Peterson, R. and G. Kimetsky). Their concerns are subsumed primarily in their anguish over the loss of transcendence in their personal and professional lives. 
It is in the nature of an educated man to live transcendentally, while remaining fully conscious of the ground realities and the adversities of his circumstances. But, something must be radically wrong with our system of education, if the politics of our corporate experience tends to generate moral despair and sociocultural conflicts. In such a climate, economic order becomes highly vulnerable to the forces which systematically hide and insidiously exploit the vested interests. Corporate system becomes a captive of capitalist greed. Money and capital become intrinsic values and value derives it's worth through its contribution to capital accumulation. The pedagogical issue our business schools have to face in such a situation is the question of freedom to accumulate capital and to make more and even more profit. Freedom, predicated upon truth, honesty, integrity, veracity and character become a secondary issue. To be true to our calling, we the teachers in the business schools must define the ways and the means to maximize corporate freedom and its manifestation as value, reflected in the creative actions and evaluative judgments.

With this thought in mind, the teaching and training exercise in our business schools must be more than a job procurement exercise; in all seriousness, it's goal must be the ethical and moral transformation of our corporate system. If our business education does not extend into the corporate culture and if our business curriculum does not reach into the farthest corners of our corporate society, the teaching and the training exercise in our business schools will remain an exercise in futility. The residual effect of what we are doing in our business schools and with such an abandon says so much more than words are likely to say.

A business school must look not only outward but also within. It must provide not only the specialized and departmental training but, with equal passion, it must also offer meaningful moral and ethical perspectives and deliver enduring sociocultural experiences with humanistic component and liberal orientation. In this regard, IBA's offering of Philosophy, Logic and Ethics course, in conjunction with Ethics in Corporate Society, as mandatory and quintessential courses for the students of business education are intended to teach our students to strive not just to be the business managers but good business managers, competing not only on specialized knowledge but also the managers willing to be wise (Sapere Aude). Such courses are meant to respond to the long felt need for reorientation of our pedagogical concern. More importantly, such courses acknowledge the fact that our corporate world-view is flawed in many ways and our business education need to draw into the fold of management not only personality ethics but also character ethics. Beside the formal training, our intent ought-to-be the liberal education of our student as a total individual, well-equipped with generalized knowledge and deep ethical and moral disposition. To achieve this goal, if it is worthy of our teaching and training exercise, we need to look beyond the fragmented specialization and the narrow confinements of our departmental training. We also need to remember that if our curiosities are keen and our pedagogical ethos is poignant enough, in management science and more so in liberal education and scholarship, the new approaches, new trends, and the yet undiscovered innovations will arise outside the given discipline itself. For insurance, if our research and teaching is pursued with a creative bias and interdisciplinary orientation, the new approaches to the study of corporate management will come out of ethics, psychology, sociology, philosophy and the fundamentals of liberal education. Paradoxically, and to our great astonishment, a great deal of such generalized knowledge and inter-disciplinary research, our corporate thinker does not consider very relevant to the teaching of (the art or) the science of management.

Nevertheless, the most current themes of the philosophy of liberal education have 
always been a deep and abiding ontological concern with the normative side of the sociocultural phenomenon. The question of value has always been a dominant theme of the liberal education and its philosophical perspective on life. Liberal imagination, while relativizing the "world-concept," sees the meaning of the world in relation to the experience of the worldliness of the world - thinking of "the world" as lived-world.

The thought here is that the world is a vacuous concept and as such it does not exist. Only the worlds exist; your's and mine, ours and theirs, idealistic and materialistic, moral and ethical, the poor-man's world, the world of a rich-man, the religious, economic, and the corporate worlds. Let us also understand that we do not live in different worlds; we, you and I, live in the same world differently. That is what makes the world a livedworld.

We, therefore, submit the following considerations which have a great deal of pertinence for our understanding of the corporate world-view. Assuming social responsibility for our corporate world means to construct and reconstruct the "given" world as-it-is into the world as-it-ought to be. Culturally such an ethical and moral concern has always been and shall always remain the abiding passion of man's creative imagination. In its futuristic orientation the lure of the world-to-be has always been a dearly held inspiration of man. Philosophers and poets, creative writers, men of vision and imagination, moral thinkers and religious leaders, through the power of word and symbol have always created this world for everyone to see. This world, the world-to-be, has always been there and it is still waiting to be discovered. Only we will not have it!

Protagoras, the Greek philosopher, very wisely observed that "reality has many faces". Indeed the perspectival variation of reality is a fact and it is equally true about the corporate reality. Since reality as such, corporate, social, economic, political, etc, is a dynamic process, continually changing and expanding, at any given point in time it is what it was not and it is not what it will be. Like time, it moves on from the past through the present into the future, carrying the burden of its imperfections and limitations, dialectically unfolding its inherent possibilities, forever and ever more changing our view of the world we know. Time is the transcendental dimension of reality and in that dimension lies the magic and the mystery of being and becoming. We cannot stop time, nor can we hasten it when all shall be one fold. It is nevertheless the invincible passion of man to dream his dreams; it is his destiny to become what he is capable of being; man has his being in the manner of becoming.

Life, as it is lived, grows out of such thoughts and imaginations. Life teaches us to have the will to think and the courage to imagine. "What would life be if we had no courage to attempt anything?"'(Vincent Van Goh). Action is an extension of thought and imagination. Where would action be if we could not dare to think or imagine anything? Human existence is almost a moral condition and man's hyphenated being-in-the-world is a trial by existence. Only he exists who, according to the ancient refrain, dares to be wise.

Two perspectives have dominated man's overview of the "world" - the world as it is, the "given" world, the world into which we have been thrown as our existential predicament. About this world, it is said that it is naïve to think that it can be otherwise, other than what it is. Such words of wisdom have always made the seekers of the world to-be angry and, in their creative rage they have always asked: why not? 
The second perspective is rooted in man's creative will. It is based on man's vision of the world as it ought to be. The corporate manager, in a state of denial refuses to believe that the corporate reality, however, stubborn it may be, is amenable to ideal and ethical construction and reconstruction, moral intepretation and transcendental movement towards the yet-to-be. Let us, therefore, not be sad or discouraged, nor should we succumb to the call of acquiescence. Let us make this world better because in that creative engagement lies the glory of man's being-in-the-world. The reconstruction of the world is not such a difficult task after all. The real task, as Camus said, is the reconstruction of man. This is a theme we have been stressing in these pages at the risk of sounding egoistic and autobiographical.

Empedocles, another pre-Socratic philosopher and a contemporary of Protagoras, dared to look into the abyss far and beyond the time when time will exist no more. Empedocles had the dialectical sweep to emphasize that irrespective of what he thinks man will never be free from his creative burden of construction and deconstruction of the lived-reality. He shall never be free from the demand of "moral imperative to act in such a way that by his will, his action becomes a law universal." So understood, man is a "particular universal." According to Empedocles, man's being in the world and his experience of various perspectives of reality is marked by two contending and opposite forces e.g. good and evil, truth and falsehood, honesty and deceit, need and greed, profit and loss. These forces are at war with each other, trying to win over the heart and the mind of man. While, outside in the corporate world, market forces are engaged in the manipulation and exploitation of ethics and economics.

Will the time ever come, if it has not already passed by us, for the institutions of business education to "ignite moral awakening" by incorporating into the dynamics of its pedagogy the belief that corporate thinker needs to think such thoughts, at least, once in his lifetime. Will the corporate manager ever look deep into the heart of nothingness, to become free to liberate himself from all that does not glorify his humanity? Of course it will add the tragic sense of life to his world-view, but that is the price he has to pay to grow older and wiser. If he can look within, long enough to experience the joy of his being in the manner of becoming, it will awaken him to the level of reflexive consciousness. In search of his authentic self, if he can endure the fear and trembling, initiated by his existential awakening, the corporate man will forever be haunted by the feeling that "he is not who he is and he is who he is not", and that he is greater than he knows and not nearly as wonderful as he can be.

Such thoughts and emotions will impart much dignity and sobriety to the selfawareness of the corporate manager, adding a great deal of character to his self-image. It will radically change the way he exercises power and authority, for such an exercise is always a reflection of his character. Like a creative thinker, he will realize that status quo is antithetical to a dynamic, progressive and transcendental world view. Like a research scholar, he will not abandon himself to a fixed point of view and a world whose worldliness carries with it the stigma: thus it is and cannot be otherwise. Like a philosopher - a seeker of truth - the corporate thinker will, whole-heartedly, search for the truth everywhere or nowhere at all. He will not cherish a world that cannot be otherwise, and in search of the world as it ought to be, he will not condemn himself to the world with a fait-accompli.

Such an attitudinal change will make the corporate functionary outgrow his hubris to face the fatal flaws in his professional orientation. His generalized knowledge, liberal 
outlook and ethico-moral bias will make him see more clearly and distinctly the anomalies inherent in the current business profession and a brutal disregard for value among business leaders. The remedy?

In his article, "The Profession of Business", published in the first volume of Harvard Business Review, Lawrence Lowell, President of Harvard, stressed the following indicators of professionalism: (1) "A high degree of generalized knowledge" (2) "Orientation primarily to community interest rather than to individual self-interest" and (3) "A high degree of selfcontrol of behavior through codes of ethics, internalized through conscious effort." These are fabulous thoughts but a business professional needs to remember that thought is the property of him who can entertain it, just as value is the possession of him who has adequately drawn it into the intimately professional sphere of his behavior and that the real possession of a man is his character. That is what Rene Descartes, the father of modern philosophy, following in the footsteps of Imam Ghazali, meant when he uttered: Cogito ergo Sum, I think, therefore, I am. Thought is a personal possession of the thinker who, consciously and with full force of his being can say: these thoughts are mine, these values belong to me and my character is my own-ness. It is who I am.

It takes time, indeed as much time as it takes, to teach a young student that it is only when a concept, an idea, a thought or a value has lain in his consciousness for as long as it is necessary to grow on him, to become an extension of his being as an action, a deed and an attitude. But, if it remains detached from his existential orientation in his livedworld, it is not of much use to him and it makes no difference in his life. Not until it has sprung into a decision, a judgment, and a choice to become his choice, his decision and his judgment, can it be the source and the origin of truth, value, virtue, goodness and honesty. This is a thought a corporate thinker must love to think, even if it is only an ideological aspiration, rather than a social fact about the professional life of the corporate manager. We should keep reminding ourselves that, as educated men and women, not to choose is also a choice, not to decide is also a decision and our reluctance to take a position is also an attitude.

Moreover, our corporate executive should have no illusions about the inevitable. To be an effective manager, he needs to guard himself against the futility of wrong reasons, remembering that "all reasoning is thinking but all thinking is not reasoning." He should always be fearful of the vengeance of truth. All judgments, decisions and evaluations, if they are not predicated on truth invite the wrath of the Law of Consequence. In the realm of ethics, there is no place for equivocation. Whoever trespasses the boundaries of the sacred domain of ethics condemns himself to the irrevocable outcome. The corporate manager should keep in mind the philosophical refrain of Protagoras about the multi-faced nature of reality. He also needs to know that some faces of reality are obnoxiously ugly. They do not beautify human mind, nor do they ennoble human soul. Among other venalities, the corporate executive must be dreadfully afraid of the seductive lure of greed, especially when it is veiled in the anonymity of character. Hidden beneath the persona, disguised as greed, such veiled reality loves to entice the lover's fool into the snare of corruption. Treading on the path of management, if the corporate executive loses his bearings and if his thoughts are not focused on the integrity of action and the veracity of judgment, he can very easily enter into the twilight zone of bad faith. In life and in management, nothing is more perilous to live by than a distorted sense of reality. Such reality is antithetical to all that is rational, ethical and human. Delightfully, this venomous "reality" resents honesty, beauty and truth. Scornfully, it blemishes character. It has deep and insidious associations with the market 
forces and human vulnerabilities. Out there in the corporate world, as in life, nothing corrupts more than the pathological collusion between the distorted realities of ethics and economics, need and greed, pride and shamelessness.

1. In fact, what gives the corporate world-view the distinctive features which make it both relevant and controversial are its manifest profit orientation and its ethically dubious character. The roots of the recurrent crisis into which corporate world has repeatedly fallen, lies in the mistaken and artificially created dichotomy between ethics and economics. The corporate world shall always tremble when ethics and economics will collide.

2- $\quad$ The grievous flaws that exist in the corporate system cannot be glossed over by saying that corruption, dishonesty, deceit and greed are not a monopoly of any particular system; they are inherent contradictions and fatal flaws in all systems of management, including the corporate system of management.

3- $\quad$ Of course not everyone is inclined to agree with such fallacious arguments and those who do not are saying that the anomalies in the corporate system are incongruous things and they should have no rightful place in the corporate worldview. However, to combat the view that ethics does not cohere with economics, the corporate thinker should not indulge in platitudinal wisdom. Rather, he must state his case analytically, and with the full force of ethical and moral persuasion. The corporate manager should convincingly establish that ethics and economics are not mutually exclusive components of corporate system, like the mutually exclusive categories of ethics - good and evil. He must have the moral conviction that the corporate world is not what it ought to be and if it ought to be what it is not then there must be in it a place for sadness and sorrow, silent groan and the tragic sense of life, ethics and morality, truth and justice, honesty and integrity, humanity and virtue, guilt and shame.

4- $\quad$ Therefore, no one should resist the need to reconstruct the corporate world-view based on the assumption that the two integral components of corporate system, ethics and economics, must be drawn into a dialectically creative and interactive relationship.

Of course, no can anyone deny that it is a tedious problem and it is due to its stubborn nature and our own recalcitrance that its resolution is not to be achieved easily and without a great deal of emotional distress and moral anguish. But the goal we are seeking, i.e. the nobility of professionalism, is no ordinary task or a mean achievement. The pursuit of such an ideal, not only sometimes but always, imposes upon the seeker an impossible task - the task to never to slow down and always to hold oneself to high ethical and moral standards.

Since the constitutive components of corporate system overlap, we cannot force them into isolated departments without doing violence to the unified and unifying structure of corporate reality. The thoughts we think about the corporate reality also overlap. Therefore, in thinking our thoughts about the corporate world, we should resist the temptation to force the corresponding structures of the reality of our thoughts into isolated compartments. Our failure to do so will simply be a reflection of our captive mind and a consequence of our one dimensional thinking. Departmentalization is the passion of specialists and specialization thrives on what Randall, in his Folklore of Management, calls the "fractionalization of 
human knowledge." But the gestaltan view of reality and the analytically integrated system of thinking aims to overcome the fractured and disjointed world-view. For the good of our students, we need to weigh the consequences of specialization and, more so, our disregard for generalized knowledge. A grave and agonizing consequence of our apathy in this regard is felt in the disappearance of transcendence from our corporate culture and world view. Due to the loss of such a hard to cultivate attitude and lacking also an appreciation for ethico-moral issues, the practitioner of corporate management has very carefully avoided the bolder and less profitable issues of the corporate affairs of human activity. He has failed to offer a creative and heuristic perspective to enlarge and deepen the culturally stifled corporate landscape by cultivating values, virtues, truth, honesty, dignity and everything that enriches human life. By default, the corporate executive faces the much delayed imperative to engage in the destruction of the unexamined belief structures of the corporate culture. To construct and reconstruct the ethos of the corporate world view and to cultivate value and beauty, truth and honesty, moral integrity and the transcendence, the corporate thinker, therefore, has to invent new analogies and metaphors, new symbols and new significations. Above all, he needs to think the thoughts he has avoided to think so far. He has to show moral courage to ask the questions he has not asked for fear of painful answers. The corporate thinker needs to develop a fresh narrative of integration of the realms of ethics and economics, fact and value, imagination and volition, action and decision into a synthesis, defining the domain of the corporate world-view.

However large a corporation may grow, it can still learn from the lessons extracted from the rise and fall of Roman Empire, the Glory that was Greece and the reason why ENRON came tumbling down. However distant in time and in place, we can still detach the corporate manager from his preoccupations to link him up with his predecessors, ethical and moral thinkers, exponents of liberal education, Follet's humanistic management, Taylor and his "scientism," sociologists and students of human nature, leaders of statecraft, men of vision and wisdom. It is a daunting task indeed. But it is only when the "moral and spiritual reawakening has been set off" that we will know, for the first time, to what extent our project is superfluous and whether any or many of our markings are irrelevant and off the mark. It is, of course, an arduous undertaking. But the corporate thinker needs to understand the tenuous relationship between morally sublime and economically prosperous. It is never too late to learn and it will do the corporate thinker good if he could learn to enjoy listening to the philosopher within to sharpen his moral vision. Let him learn to take delight in his reflective solitude to explore in depth various dimensions of his personality, to judge and to evaluate the moral fiber of his character. Our schools of business education, to achieve the desired goal of producing the well-rounded managers, must create an environment to promote the culture of reflexive consciousness. In today's knowledge based economy, it is not just the form of higher education, but the generalized knowledge and liberal outlook, the character and nature of education which matters the most. Ethical and the economic spheres of corporate system overlap and, in the mysterious grey spaces, loss can be the loss of values and profit can be measured by the dignity and the grace of character.

In his article, A New Code of Business Ethics, published in The New York Times Magazine (April 8, 1962), Randall talks about the moral crisis that has put a question mark on the integrity of the corporate managers and has led us to wonder "whether by any chance the whole lot of us (the corporate managers) are dishonest". Randall recounts various types of venalities and the moral crisis characterizing the corporate world, according to him, "highlights the challenge to our business leadership." He believes that the "question of moral integrity and ethical heritage cannot be glossed over in the light of economic prosperity 
https://ir.iba.edu.pk/businessreview/vol6/iss2/1

DOI: https://doi.org/10.54784/1990-6587.1189

Business Review - Volume 6 Number 2

July - December 2011

and business flourish." Randall makes no secret of his Kantianism in business ethics and our acceptance of it as a categorical imperative. It is "the acid test of our integrity.... Either we have a code of morals or we do not. We can and must set off a moral and spiritual reawakening but to do so we must not only have the moral courage to do the right but sufficient insight to know the right. Our minds must be clear, as well as our consciences." 唪

Tufail A. Qureshi 